DOI https://doi.org/10.30525/978-9934-26-047-6-31

\title{
ОЦІНКА АДАПТАЦІЙНИХ МОЖЛИВОСТЕЙ ОСІБ ЮНАЦЬКОГО ВІКУ
}

\author{
Волошин О. С. \\ кандидат біологічних наук, доцент, \\ доиент кафедри загальної біології \\ та методики навчання природничих дисииплін
}

Тернопільський національний педагогічний університет

імені Володимира Гнатюка

м. Тернопіль, Украӥна

Гуменюк Г. Б.

кандидат біологічних наук, доиент, доиент кафедри загальної біології

та методики навчання природничих дисииплін

Тернопільський національний педагогічний університет

імені Володимира Гнатюка

м. Тернопіль, Украӥна

Волошин В. Д.

кандидат медичних наук, доцент, дочент кафедри патологічної анатомії

з секиійним курсом та судовою медициною

Тернопільський національний медичний університет

імені I. Я. Горбачевського Міністерства охорони здоров'я Украӥни м. Тернопіль, Украӥна

Дослідження адаптаційних можливостей людини $є$ фундаментальним напрямком у сучасній фізіології. Особливої актуальності він набуває за умов істотних змін існування, що отримали розвиток в останні десятиріччя: гіподинамія, інформаційне навантаження, гіпокінезія, зміна добового режиму, значене поширення цифрової техніки і використання гаджетів як у професійній діяльності, так і в побуті. Стосовно студентської молоді перелік зазначених змін доповнюють значні інтелектуальні та психо-емоційні навантаження, що в кінцевому рахунку, негативно впливають на здоров'я студентів і можуть ініціювати зниження адаптаційних можливостей організму $[2$, c. $36 ; 3$, c. $13 ; 4$, c. $66 ; 5$, c. 25$]$. 
Актуальність цього напряму досліджень протягом останніх десятирічь сприяла розвитку функціональної діагностики і розробці нових методів і підходів для дослідження адаптаційних можливостей, серед яких - індекс функціональних змін за А. П. Берсеньовою, визначення адаптаційного потенціалу за Р. М. Баєвським [1, с. 38; 6, с. 128]. 3 метою аналізу адаптаційних можливостей організму традиційно використовують дослідження показників роботи кардіореспіраторної системи, показників фізичного розвитку, рівня працездатності та функціональної ефективності нервової системи, специфіки обробки сенсорної інформації.

В роботі 3 метою оцінки рівня адаптаційних можливостей осіб юнацького віку (19-20 років) досліджували показники артеріального тиску до і після фізичного навантаження, аналізували індекс Робінсона, якість реакції серцево-судинної системи на фізичне навантаження за Кушелевським, визначали тип конституції обстежених, рівень лабільності нервової системи, вираженість екстра/інтроверсії, силу нервової системи.

В стані спокою систолічний артеріальний тиск мав значення $112,25 \pm 2,09$ мм рт.ст., значення діастолічного склало $71,13 \pm 2,13$ мм рт.ст. Дозоване фізичне навантаження зумовило зростання систолічного тиску на 19,64\%, значення діастолічного при цьому знизилось на 7,69\%, що вказує на рефлекторне розширення периферичних судин для інтенсифікації кровопостачання скелетних м’язів і зменшення загального периферичного опору. Такий тип реакції $\epsilon$ нормотонічним і оптимальним для збільшення хвилинного обсягу кровотоку, що сприяє адекватній адаптації до фізичного навантаження. Значення індексу Робінсона, що відображує систолічну роботу серця, в обстежених юнацького віку склало 83,74 $\pm 1,13$ і відповідає нормі за умов спокою. Слід відзначити, що серед обстежених домінуюча частка осіб - 43,75\% мали середній рівень функціональних резервів серця за індексом Робінсона, ще в 37,5\% осіб відзначено низький рівень і лише у 18,75\% обстежених юнацького віку спостерігали високий рівень цього показника.

Успішність адаптації до фізичного навантаження $\epsilon$ вагомим показником загального рівня адаптаційних можливостей організму, оскільки відображує одночасно не лише функціональні резерви скелетної мускулатури, але й можливості кардіореспіраторної системи та ефективність нейрогуморальної регуляції. Оцінка якості реакції серцево-судинної системи на дозоване фізичне навантаження за Кушелевським показала, що добрий рівень реакції - лише в 38,5\% осіб, в $61,5 \%$ обстежених показник реакції мав нижчий рівень. 
За результатами тепінг-тесту встановлено високу лабільність нервової системи у $75 \%$ обстежених. Ще $25 \%$ осіб мали середній рівень лабільності, низькі значення відсутні. Це можна розцінювати як показник значної функціональної пластичності нервових процесів, адекватної швидкості реакції і ефективної обробки нової інформації обстеженими особами юнацького віку.

Дослідження показали, що в обстежених домінуючим типом конституції $є$ нормостенічний - 73,2 \% осіб, в решти осіб було встановлено астенічний тип, особи з гіперстенічним типом конституції відсутні. Аналіз рівня екстра/інтроверсії засвідчив, що в обстежених домінує помірно виражена екстраверсія: $67,9 \%$, другим за значенням був показник помірно вираженої інтроверсії - 21,5\% осіб. При цьому в осіб з нормостенічним типом конституції переважає середньо-сильний тип нервової системи, що відповідним чином впливає на перебіг процесів збудження і гальмування та працездатність нервових центрів. В осіб з астенічним типом тілобудови переважає середньо-слабкий тип нервової системи, що може потенційно зменшувати рівень працездатності їх нервових центрів.

Отже, в обстежених осіб юнацького віку переважає нормостенічний тип конституції, рівень функціональних резервів серця за індексом Робінсона відповідає нормі, реакція серцево-судинної системи на фізичне навантаження нормотонічного типу, що сприяє збільшенню хвилинного обсягу кровотоку і оптимізує кровопостачання відповідних скелетних м'язів. Висока пластичність нервових процесів, домінування помірного ступеня екстраверсії та інтроверсії серед обстежених сприяють розвитку когнітивних функції центральної нервової системи i формуванню ефективних механізмів комунікації, необхідних для пристосування до умов середовища. Усе зазначене можна розцінювати як сприятливі фактори для успішної адаптації. Водночас, в 37,5\% осіб відзначено низький рівень індексу Робінсона, показник реакції на фізичне навантаження за Кушелевським в 61,5\% обстежених мав низьке значення, що може свідчити про недостатній ступінь тренованості серцево-судинної системи цих осіб юнацького віку.

\section{Література:}

1. Босенко A.I., Пліско В.I., Топчій М.С., Сінько І.С. Дискусійні аспекти оцінки адаптаційних можливостей школярів, за даними індексу функціональних змін. Вісник Чернігівського національного педагогічного університету. 2017. № 147. Т. 1. С. 38-44. 
2. Воскобойнікова Г. Л. Концепція комплексної оцінки адаптаційних можливостей у формуванні і збереженні індивідуального здоров'я людини. "Наука і освіта". 2014. №8. С. 35-39.

3. Дерека Т.Г., Туманова В.М., Бистра I.І., Гацко О.В. Оцінка адаптаційного потенціалу серцево-судинної системи студентів I курсу. Journal «ScienceRise: Pedagogical Education». 2017. №10(18). C. 13-17.

4. Леонтьєва Зоряна. Розрахунок адаптаційного потенціалу, оцінка адаптаційних можливостей організму i рівнів здоров'я студентів Львівського національного медичного університету імені Данила Галицького. Прачі НТШ Медичні науки. Оригінальні дослідження: клінічні науки . 2017. Т XLVII. C. 64-70.

5. Чернявська Л.І., Криницька І.Я., Мялюк О.П. Стан здоров'я студентів, проблеми та шляхи їх вирішення. Медсестринство. 2017. № 1. С. 24-27.

6. Чертановський П.М. Аналіз функціонального стану серцевосудинної системи у юнаків студентського віку. Проблеми фізичного виховання $і$ спорту. Педагогіка, психологія та медико-біологічні проблеми фізичного виховання і спорту. 2012. № 2. С. 128-131.

DOI https://doi.org/10.30525/978-9934-26-047-6-32

\title{
ПОРІВНЯЛЬНА ХАРАКТЕРИСТИКА СТАНУ ІНТИМА- МЕДІАЛЬНОГО КОМПЛЕКСУ ЗАГАЛЬНОЇ КАРОТИДНОЇ АРТЕРІЇ ТА ПОКАЗНИКІВ ЛІПІДОГО ОБМІНУ У ХВОРИХ З ІХС НА ТЛІ ЦУКРОВОГО ДІАБЕТУ 2-ГО ТИПУ
}

\author{
Горевич С. С.
}

аспірант кафедри пропедевтики внутрішніх хвороб

Буковинський державний медичний університет

м. Чернівиі, Україна

\author{
Скорейко Н. Т. \\ лікар-кардіолог вищої категорії \\ КП «Рівненська обласна клінічна лікарня» Рівненської обласної ради \\ м. Рівне, Украӥна
}

Серцево-судинні захворювання (СС3) $є$ основною причиною смертності хворих з цукровим діабетом (ЦД). Пацієнти 3 ЦД в середньому у 3 рази частіше страждають цереброваскулярними 